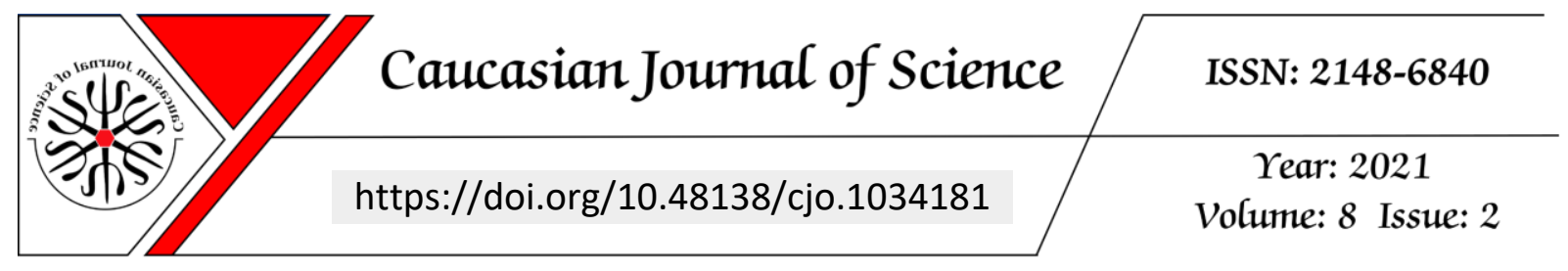

\title{
Thermal Camera Use for Evaluation of Patients and Injured in Chemical, Biological, Radiological, Nuclear Events
}

\author{
Çağatay KADiRSOY${ }^{1}$, Gökhan NUR ${ }^{2}$, Hüseyin KAFADAR ${ }^{3}$
}

Makalenin Alanı: Sağlık Bilimleri, Mühendislik

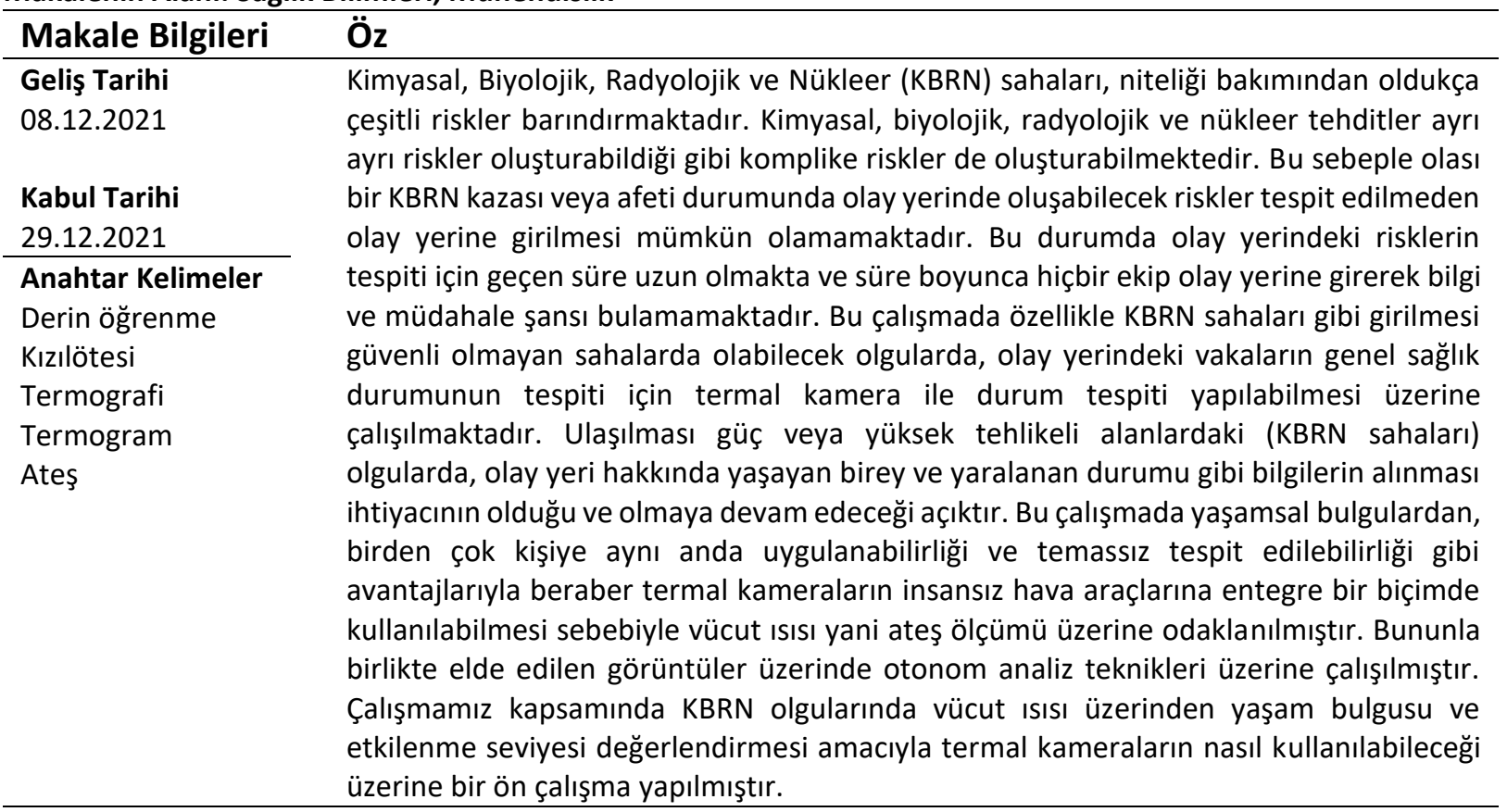

\begin{tabular}{l}
\hline Article Info \\
\hline Received \\
08.12 .2021 \\
Accepted \\
29.12.2021 \\
\hline Keywords \\
Deep Learning \\
Infrared \\
Thermography \\
Thermogram \\
Feverly
\end{tabular}

\section{Abstract}

Chemical, Biological, Radiological, Nuclear (CBRN) areas contain various risks due to their structure. Chemical, biological, radiological, and nuclear threats can create separate or combined risks. For this reason, it is not possible to enter the scene safely without detecting the risks that may occur in a possible CBRN accident or disaster. Since the risk assessment in the incident area takes a long time, no team can enter the scene and find information and intervention until the risk assessment is done.

In this article, it is studied the determination of the general health status of people in hazardous CBRN zones via a thermal camera. It is obvious that there is a continuous need to obtain information about the scene of the incident such as the alive, sick, and injured people in the situation of hard-to-reach and highly hazardous CBRN areas. In addition, autonomous analysis techniques were studied on the obtained images.

In this study, it is focused on the determination of health status according to body temperature measurement, which is one of the vital signs, by the advantages of applying to more than one person without contact provided by thermal cameras integrated into a UAV. In addition, autonomous analysis techniques were studied on the

\footnotetext{
1 İskenderun Teknik Üniversitesi KBRN Tehditleri Yönetimi- Hatay; e-mail: cagataykadirsoy@gmail.com; ORCID: 0000-0002-8587-7826

2 isskenderun Teknik Üniversitesi Biyomedikal Mühendisliği- Hatay; e-mail: gokhan.nur@iste.edu.tr; ORCID: 0000-0002-5861-8538

${ }^{3}$ Adıyaman Üniversitesi Tıp Fakültesi Dahili Tıp Bil.- Adıyaman; e-mail: hkafadar@adiyaman.edu.tr; ORCID: 0000-0002-6844-7517
} 
obtained images. Within the scope of the study, a preliminary study was implemented on how thermal cameras can be used to evaluate vital signs in CBRN cases and to evaluate exposure levels according to body temperature.

\section{Introduction}

Today, vital signs can be easily observed with current technologies in disasters and emergencies where many people are affected. As it is known, the first step in all disaster and emergency cases, scene safety comes first in the response process. Also, considering the chemical, biological, radiological, and nuclear threats, it is extremely important how to treat people exposed to the incident. In this case, it is extremely important to get information about the general health condition of the people exposed to the incident and determine how many people were affected as sick or injured by the CBRN incident and calculate the probability of survival (Richard et al., 2013).

In this study, the approach of collecting the local or general body temperature data of affected people is proposed to understand the damage caused by CBRN threats. According to this approach, the possibility of determining the health condition of the affected people is studied by analyzing the data obtained from the thermal camera images.

The main purpose of the study is to put a preliminary study on the effect of thermal cameras for obtaining vital signs in various CBRN incidents. Crime scene safety is achieved quickly in many cases but in CBRN situations it is difficult to ensure (AFAD, 2021). The main reason is CBRN incidents are complex cases. Many CBRN research and application studies in the fields of industry, energy, and health have indirectly increased the probability of accidents. The accidents that occurred during these studies have taken a place in memory as they have caused many fatal disasters in the history of the world (Ekşi, 2016). It must keep in mind that CBRN agents can be used as weapons of war or for terrorist purposes. Expanding impact areas and successional CBRN reactions may occur in CBRN attacks or CBRN disasters (Sarı and Seyhan, 2012; Marsella and Sciaretta, 2018).

For this reason, a contactless, non-invasive, and remotely controllable analysis technique compared to existing measurement technologies was deemed necessary to evaluate the conditions of people in CBRN events. In this manner, the usability of the thermography method relating to body temperature data for vital sign detection has been investigated. 


\section{Body Temperature (Fever)}

Since the earliest times, body temperature has been seen as one of the most basic vital signs. The main reason is body temperature has a quite wide etiology. It appears as the main variable in many cases such as inflammatory (infectious) diseases, various enzyme and hormonal changes in endocrinology, chemical agent or drug use, radiation absorption, and death. Body temperature changes obser ve most effectively on the skin. Body temperature change has been observed most effectively on the skin. The body temperature causes radiation emitted from the skin and the radiation level can be measured by infrared spectroscopy. (Ring et al., 2010).

\section{Body temperature variability in CBRN circumstances}

According to analysis, it is observed that CBRN agents caused direct or indirect variability in body temperature. It is known that most biological infectious agents increase body temperature (Erkekoğlu and Koçer, 2018). In addition, the direct effects of radiation in radiological incidents on body temperature are known. In nuclear incidents, a specific increase occurs in body temperatures according to the ambient temperature rise due to radiation (Ayan and Dönmez, 2018). Chemical agents cause various reactions on the body and indirectly cause changes in body temperature (Ganesan et al., 2010).

Mass deaths are one of the most negative situations that may happen in CBRN incidents. It is especially important to get information about the number of dead and alive in the CBRN area. In a death situation, the metabolic activities gradually decrease and stop. Thermal cameras provide highly specific life-saving information in this field.

Due to the wide etiology of body temperature, it is difficult to determine what kind of CBRN agent caused the body temperature change. For this reason, it is hard to make a definite diagnosis based on body temperature. However, detecting the common body temperature variability will strengthen the assumption of influence and simplify the elimination of misdiagnoses. For this reason, observation with a thermal camera in CBRN incidents is promising as it saves time by performing collective analysis.

\section{Infrared radiation and human infrared}

Electromagnetic radiation waves cover a very wide range of wavelengths and frequencies between gamma rays and radio waves. The infrared spectrum represents the part 
after visible light in the region of non-ionizing radiation. The wavelength of infrared radiation is 0.75-1000 $\mu \mathrm{m}$ (micrometers) (Gade and Moeslund, 2014; Balcl and Sensoy, 2004).

Every object above zero temperature emits a specific infrared wave. The wavelength, and frequency of the emitted infrared radiation change in direct proportion with object temperature. Although this wide range of radiation, the infrared waves emitted by a normal person are in a very narrow range of $8-12 \mu \mathrm{m}$. So, thermal images can provide distinctive data (Psokoski, 2000; Usamentiaga et al., 2014).

\section{Thermal infrared cameras and their usage areas}

Thermal imaging studies were first started on night vision in the USA in the 1940s. Studies have progressed day by day and had been used in many fields, up to today's modern thermography technique (Gade and Moeslund, 2014). A thermal infrared camera detects infrared waves emitted by an object and converts them into electronic signals and creates thermal images. While the thermal images are defined as thermograms, the name of this technique is defined as infrared thermography (IRT) (Usamentiaga et al., 2014). Infrared thermography has many advantages:

1. IRTs are non-contact thermometers: there is no need to contact the heat source for measurement. In this way, extremely hot objects, or dangerous products such as acids can be safely measured and keep the user out of danger.

2. IRT provides two-dimensional thermal images that users can make comparisons between target areas.

3. IRT quickly scans stationary targets, fast-moving targets and compares rapidly changing thermal patterns.

4. IRT has no harmful radiation effects like X-ray imaging technology has. It is suitable for longterm and repeated use.

5. IRT is a non-invasive and painless technique. There is no interventional interference with the target in any way (Speakman and Ward, 1998).

One of the most critical areas of use of thermal cameras is human thermal imaging. The infrared thermal imaging studies were first found for night vision purposes in the 1940-1950s, human use studies started in 1963. The first infrared thermograms appeared in the black and white format (Barnes, 1963). 
Infrared thermography (IRT) is a fast, passive, and non-invasive technique compared to other techniques. The biggest advantage of body temperature analysis with a thermal camera is thermal cameras do not need to focus on a single point. Thus, body temperature obtained according to thermal image can give an idea about a large part or all the body. Body temperature distribution can be seen as an inhomogeneous color map in thermal camera measurements. The main reason is the various parts of the body are at different temperatures and their surface areas are variable. For this reason, when there is a local temperature increase, a color change is also observed in the thermal camera. Other advantages are, thermal cameras are not affected by the skin color of humans, produce thermal images independently of daylight, and capture images on a large group of people at the same time (Ivanescu and Ciupitu, 2010; Tkáčová et al., 2011).

Considering the latest technologies, the use of special thermal infrared imagers in the medical field is increasing day by day. It is used successfully in the field, especially in the detection of cancer types, diabetes, neuropathy, peripheral vascular disorders, and many similar diseases, and it can also be used in research such as the variables of activity result and the investigation of body comfort (Ivanescu and Ciupitu, 2010; Jackers, 2014).

Today, advanced thermal imaging devices with high sensitivity are being developed and used, especially in the medical field. The human body is variable in terms of vascular structure, muscle distribution, distribution of joints, skin thickness, regions of organs, and endocrinological factors that cause temperature differences in terms of body regions apart from various illnesses. Due to this variability, body temperature is not distributed homogeneously. For this reason, very distinctive features are observed in terms of color distribution in human thermography (Lahiri et al., 2012).

\section{Use of thermal camera in disaster or accident situations}

Firefighters, search and rescue personnel, emergency medical personnel, and security units can benefit from the use of thermal cameras in case of an accident or disaster (Doherty and Rudol 2008). The main reason is thermal cameras can be used in many areas such as scene security, number, and location of the sick and injured people, emergency classification of the sick and injured people (Amon et al., 2005). Many field examples can be given such as remotely detecting casualties in a large area, detecting overheated areas, making risk analysis in the crisis area, using night vision feature for search and rescue in a dark area, detecting 
general information of health condition of people, disease diagnosis, and eliminating misdiagnoses. (Amon et al., 2005; Doherty and Rudol 2008).

Although thermal cameras are a very efficient technology on their own, they can be used in combination with various robotic systems according to the characteristics of the research field today (Lock and Amon, 2008). Images taken from the thermal camera can be instantly transferred to long distances via mobile network systems. The location tracking can be made via GPS systems. In the search and rescue field, thermal cameras integrated onto UAVs and combined with a mobile network system and GPS system are used. (Amon and Lock, 2008; Rodin et al., 2018). Unmanned aerial vehicles (UAVs) are defined as reusable motorized aircraft that can be remotely controlled autonomously or semi-autonomously without a manned pilot, depending on the task to be performed, and that perform special tasks in the atmosphere or outside for a certain period, with different loads depending on their characteristics (Blyenburgh Van, 1999). It offers very economical and practical solutions to affordable prices, especially due to its remote-control capability.

Another technology is the smartphones with thermal camera features, as well as thermal cameras with the ability to connect to phones with simple interfaces (Rodin at al., 2018). In this way, the use of thermal cameras in the relevant field has become extremely easy and accessible. In addition, today's technology works on the processing and classification of images. Through the help of software, people detection, counting, and situation analysis can make simultaneously (Lee et al., 2015). In this way, automatic thermal image analysis becomes possible with remotely controlled UAVs in case of disasters and CBRN incidents. Its usability is promising especially in dangerous situations where incident scene safety cannot be provided. The research has been done on the use of thermal cameras in the CBRN field, and it is concluded that deep learning studies with thermographic data in CBRN fields will yield successful results (Nguyen et al., 2017; Arora and Singh, 2020).

\section{Global difficulties for thermal camera use in CBRN field}

Infrared Thermography is a sensitive measurement technique due to its structure. Working with Infrared Thermography, it is necessary to consider many factors that affect the interpretation of thermographic data, so the results are consistent and meet validation parameters. These factors are divided into three main groups as environmental factors, individual factors, and technical factors (Quintana and Sillero, 2015). 
Environmental factors are related to the environment in which the measurement is made. These are ambient size, ambient temperature, relative humidity, atmospheric pressure, and ambient radiation level. The ambient size should be wide enough to meet the factors such as the distance and angle required to take the image. Ambient temperature, atmospheric pressure, and relative humidity level affect the body temperature of living objects in the environment. The ambient radiation intensity also should not be ignored, as the radiation level can both increase the temperature of the living thing and degrade the infrared wavelength (Shterenshis, 2017).

Individual factors are gender, age, anatomical features (height, weight), physiological characteristics (metabolism rate, hormonal status, skin blood supply level), circadian rhythm (the amount of heat exchange between various times of the day), hair density, skin emission, medical condition (genetic factors, food intake status, drug intake, use of various chemicals). It should be considered that most of these factors can influence body temperature, as well as the clarity of the thermal image. Technical factors are accuracy, reliability, technical protocols, distance vision capability, camera position and angle, camera features (temperature range, resolution, margin of error) (Shterenshis, 2017).

To standardize these factors, the University of Glamorgan has prepared the Glamorgan protocol as a standardization that will form the basis for medical thermography. Although it may seem complex to have so many variables for thermal imaging, it should be considered during studies (Ammer, 2008).

\section{Conclusion}

In this study, new techniques were discussed to obtain information on the overall level of exposure, number of dead and alive, or to make a preliminary assessment in terms of exposure in a CBRN event. The focus of the study is the Infrared Thermal Imaging (IRT) technique via body temperature for non-contact, non-invasive, simultaneous measurement, and simultaneous scanning of a group of people.

Body temperature is one of the basic vital signs with a wide etiology. It is obvious that many diseases, physiological variables, and death status influence body temperature. In this study, a detailed literature review has been made over body temperature changes that occurred in CBRN instances (Uzun, 2007; Ring et al., 2010). The technical study could not be performed due to the difficulty of finding samples affected by CBRN agents. When previous 
studies were investigated, it is observed that chemical agents, especially nerve agents and some capacity-disrupting agents, directly affect body temperature. And caustic, turmoil control, and suffocating agents indirectly affect body temperature in both the short and long term (Ganesan et al., 2010; Clark, 1979). In biological agent exposure, despite the effects has not seen quickly, it is observed that all infectious microorganisms can cause changes in body temperature (Erkekoğlu and Koçer, 2018; Kılıç, 2006). It has been observed that the body temperature rises in direct proportion with the absorption of radiation in radioactive events or in acute radiation syndrome. In nuclear incidents, it is found that body temperature changes are observed in proportion to the radiation emission to the environment (Ayan and Dönmez, 2018; Özcan and Topçuoğlu, 2008). More increase has been observed in body temperature in the CBRN area that is exposure to chemical agents, biological agents, or radiation. As an example, in choking agents, an increase in temperature in the chest due to lung infection is expected, while in caustic agents, the temperature increase is expected more in the face area where the mucosa density is more. Biological agents also cause a predominant increase in temperature in the infected tissues. It is observed that this situation caused a change in the non-homogeneous distribution of normal body temperature.

In the rest of the study, body temperature measurement technologies were investigated, and research was made on the usability of the Infrared Thermal Imaging (IRT) technique in CBRN events. The advantages of infrared thermal cameras indicate the various level of body temperature in assorted colors, the simultaneous analysis of a whole part of the body or a large group of people, and the applicability of autonomous image processing and classification techniques with deep learning, which is an area of artificial intelligence, were considered and the infrared thermography technique was recommended. By the infrared thermography method, the body temperature change and the body temperature distribution can be analyzed. The thermogram image of the body under normal conditions and under the presence of the CBRN agents can be compared for differences (Ivanescu and Ciupitu, 2010; Tkáčová et al., 2011). For example, the temperature level close to the radioactive material is higher than in other regions, and the color of the region in the thermogram image is expected to turn towards red tones. In addition, the usability of infrared thermal cameras with different technologies has been investigated. It is seen that the usability of thermal cameras and the obtained images can be transferred simultaneously with mobile networks via long distances, without entering the CBRN zone (Amon and Lock, 2008; Rodin et al., 2018). 
In this study, it is seen that body temperature analysis can be performed by using Infrared Thermal Cameras in CBRN events, disasters, and emergency zones, and preliminary information can be given on the presence of CBRN exposure. From this point, this study showed that infrared thermography (IRT) is a highly promising method for CBRN exposure level measurement.

\section{Conflict of Interest Statement}

There is no conflict of interest between the authors.

\section{REFERENCES}

Ammer, K.(2008). The Glamorgan Protocol for recording and evaluation of thermal images of the human body. Thermol Int, 18 (4), 125-44.

Amon, F. K., Bryner, N. P., and Hamins, A. (2005). Thermal imaging research needs for first responders: workshop proceedings. US Department of Commerce, Technology Administration, National Institute of Standards and Technology.

Ayan, A., and Dönmez, S. (2018). Radyolojik Nükleer Kaza ve Terör Olaylarında Tıbbi Yönetim. Ankara Eğt. Arş. Hast. Dergisi, 51(2), 154-162.

Barnes, R.B. (1963). Thermography of the Human Body: Infrared-radiant energy provides new concepts and instrumentation for medical diagnosis. Science, 140(3569), 870-877.

Clark, W. G. (1979). Changes in body temperature after administration of amino acids, peptides, dopamine, neuroleptics and related agents, Neuroscience \& Biobehavioral Reviews, 3(4), 179-231.

Ekşi, A. (2016). Kbrn Terörizminde Risk Değerlendirmesi Ve Yönetimi, Journal of International Social Research, 9(42).

Erkekoğlu, P., and Koçer-Gümüşel, B. (2018). Biyolojik Savaş Ajanları: Tarihçeleri, Patofizyolojileri, Tanıları, Tedavileri ve Önlemler. FABAD Journal of Pharmaceutical Sciences, 43(2), 81-111.

Gade, R., and Moeslund, T.B. (2014). Thermal cameras and applications: a survey. Machine vision and applications, 25(1), 245-262.

Ganesan, K., Raza, S.K., and Vijayaraghavan, R. (2010). Kimyasal savaş ajanları. Eczacllık ve Biyoallied Bilimler Dergisi, 2(3), 166.

Ivanescu, N.A., and Ciupitu, L. (2010). Vision system for human body infrared thermography. In 19th International Workshop on Robotics in Alpe-Adria-Danube Region (RAAD 2010) (pp. 353-356). IEEE.

Jockers. D. (2014). Thermography: Is This The Best Breast Screening Device, https://drjockers.com/thermography-breast-screening/. .

Uzun, N.K. (2007). Fever and feverly ill management. The Medical Bulletin of Sisli Etfal Hospital, 41(4), 7-13.

Kilıç, S. (2006). Biyolojik silahlar ve biyoterörizm. Türk Hijyen ve Deneysel Biyoloji Dergisi, 63(1), 2. 
Lahiri, B.B., Bagavathiappan, S., Jayakumar, T., and Philip, J. (2012). Medical applications of infrared thermography: a review. Infrared Physics \& Technology, 55(4), 221-235.

Lee, F.F., Chen, F., and Liu, J. (2015). Infrared thermal imaging system on a mobile phone. Sensors, 15(5), 1016610179.

Lock, A., and Amon, F. (2008). Measurement of the nonuniformity of first responder thermal imaging cameras. In Infrared Imaging Systems: Design, Analysis, Modeling, and Testing XIX (Vol. 6941, p. 694114). International Society for Optics and Photonics.

Marsella, S., and Sciarretta, N. (2018). CBRN Events and Mass Evacuation Planning, In Enhancing CBRNE Safety \& Security: Proceedings of the SICC 2017 Conference (pp. 353-363). Springer, Cham.

Nguyen, D.T., Kim, K.W., Hong, H.G., Koo, J.H., Kim, M. C., and Park, K.R. (2017). Gender recognition from humanbody images using visible-light and thermal camera videos based on a convolutional neural network for image feature extraction. Sensors, 17(3), 637.

Özcan, M., and Topçuoğlu, P. (2008). Akut Radyasyon Sendromu. Nükleer Kaza veya Terörist Atakta Hematopoietik Kök Hücre Transplantasyon Stratejisi. Ed. Fikret Arpacı, Mutlu Arat. Bilimsel Tıp Yayınevi. Sayfa 33-41.

Prokoski, F. (2000). History, current status, and future of infrared identification. In Proceedings IEEE Workshop on Computer Vision Beyond the Visible Spectrum: Methods and Applications (Cat. No. PR00640) (pp. 514). IEEE.

Richardt, A., Hülseweh, B., Niemeyer, B., and Sabath, F. (Eds.). (2013). CBRN protection: Managing the threat of chemical, biological, radioactive and nuclear weapons, Part 1. History and Treaties in CBRN-Warfare and Terrorism ( pp.2-8).

Ring, E.F.J., McEvoy, H., Jung, A., Zuber, J., and Machin, G. (2010). New standards for devices used for the measurement of human body temperature. Journal of medical engineering \& technology, 34(4), $249-253$.

Rodin, C. D., de Lima, L. N., de Alcantara Andrade, F. A., Haddad, D. B., Johansen, T. A., and Storvold, R. (2018). Object classification in thermal images using convolutional neural networks for search and rescue missions with unmanned aerial systems. In 2018 International Joint Conference on Neural Networks (IJCNN) (pp. 1-8). IEEE.

Rudol, P., and Doherty, P. (2008). Human body detection and geolocalization for UAV search and rescue missions using color and thermal imagery. In 2008 IEEE aerospace conference (pp. 1-8).

Sensoy, B., and Balci, H. (2004). Thermal imaging technology and applications in Turkey. In Proceedings of the IEEE 12th Signal Processing and Communications Applications Conference, 2004. (pp. 661-664). IEEE.

Seyhan, E., and Sarı, G. (2012). Terör Maksatlı Biyolojik-Kimyasal Saldırılara Ait Tehdit Değerlendirmesinde Risk Analizi ve Yönetimi, Güvenlik Bilimleri Dergisi, 1(1), 79-94.

Sillero-Quintana, M. (2015). Classification of factors influencing the use of infrared thermography in humans: A review. Infrared Physics \& Technology, 71, 28-55.

Singh, J., and Arora, A.S. (2020). Automated approaches for ROls extraction in medical thermography: a review and future directions. Multimedia Tools and Applications, 79(21), 15273-15296. 
Speakman, J.R., and Ward, S. (1998). Infrared thermography: principles and applications. Zoology-Jena-, 101, 224-232.

Shterenshis, M. (2017). Challenges to global implementation of infrared thermography technology: current perspective. Central Asian journal of global health, 6(1).

T.C. İçişleri Bakanlığı Afet ve Acil Durum Yönetimi Başkanlığı (AFAD), (Ocak, 2021). KBRN Terimler Sözlüğü.

Tkáčová, M., Hudák, R., Živčák, J., and Sidun, J. (2011, June). Thermographic atlas of the human body. In 2011 15th IEEE International Conference on Intelligent Engineering Systems (pp. 427-429). IEEE.

Usamentiaga, R., Venegas, P., Guerediaga, J., Vega, L., Molleda, J., and Bulnes, F.G. (2014). Infrared thermography for temperature measurement and non-destructive testing. Sensors, 14(7), 12305-12348.

Van Blyenburgh, P. (1999). UAVs: an overview. 1(5-6), 43-47. 